\title{
Hak Warga Negara Untuk Mendapatkan Pelayanan Kesehatan Berdasarkan HAM dan UUD 1945
}

Muhammat Al Farisi Institut ilmu kesehatan Strada Indonesia e- mail: farisfaris22779@gmail.com

\section{Abstrak}

Pelayanan kesehatan merupakan kebutuhan primer dalam kehidupan setiap manusia, dan merupakan hak untuk mendapatkannya, maka setiap orang membutuhkan kondisi badan sehat agar mampu menjalankan aktivitas sehari-hari guna mencapai hidup sejahtera. Selain hal tersebut, kesehatan merupakan Hak Azasi Manusia dan salah satu unsur kesejahteraan masyarakat yang harus diwujudkan sesuai citacita bangsa Indonesia, sebagaimana yang dimaksud dalam Pancasila dan UUD 1945. Selanjutnya bahwa setiap kegiatan dalam upaya untuk memelihara dan meningkatkan derajat kesehatan masyarakat yang setinggi-tingginya, dilaksanakan berdasarkan prinsip non-diskriminasi, partisipatif dan berkelanjutan dalam rangka sumber daya manusia Indonesia, 
serta meningkatkan ketahanan dan daya saing bangsa bagi pembangunan nasional. Dalam setiap hal yang menyebabkan terjadinya gangguan kesehatan pada masyarakat Indonesia, akan menimbulkan kerugian ekonomi yang besar bagi negara, dan setiap upaya untuk meningkatkan derajat kesehatan masyarakat juga merupakan investasi bagi pembangunan negara. Oleh sebab itu, setiap upaya pembangunan harus dilandasi dengan wawasan kesehatan dalam artian pembangunan nasional harus memerhatikan kesehatan bagi masyarakat dan tentu saja harus merupakan tanggung jawab semua pihak baik bagi pemerintah, maupun bagi masyarakat. Pasien peserta program prolanis yang ada di puskesmas grogol " RAHMATIKA" merupakan warga negara Indonesia yang membutuhkan pelayanan kesehatan untuk dirinya maupun keluarganya. Mengingat peserta program prolanis, yang sangat membutuhkan pelayanan kesehatan, namun masih banyak yang tidak menggunakan kesempatan untuk mendapatkan pelayanan kesehatan yang dimilikinya.

\section{Latar belakang}

Pengabdian Kepada Masyarakat ini dilaksanakan untuk memberikan pengetahuan dan pemahaman tentang hukum yang berlaku di Negara Kesatuan Republik Indonesia dengan tujuan mengerti dan memahaminya masyarakat di bidang hukum. Pada kesempatan kali ini, kegiatan pengabdian masyarakat dilaksanakan di puskesmas grogol "RAHMATIKA"

Desa Sonorejo, RT 07 RW 01, Kecamatan Grogol Kabupaten Kediri. Kegiatan Pengabdian Masyarakat ini bertujuan untuk memberikan edukasi dan pemahaman kepada warga 
masyarakat tentang " Hak Warga Negara Untuk mendapatkan Pelayanan Kesehatan Berdasarkan Undang Undang Dasar Tahun 1945".

Kesehatan merupakan kebutuhan utama bagi perseorangan, keluarga atau masyarakat. Selain merupakan kebutuhan utama, disamping kebutuhan utama lainnya yang berupa papan, pangan dan sandang/pakaian, maka kesehatan merupakan kebutuhan yang utama yang keempat. Oleh sebab itu kesehatan merupakan kebutuhan manusia, karena dengan kesehatan manusia dapat dan mampu beraktivitas menjalan kan kegiatannya untuk memenuhi kebutuhan hidupnya baik kebutuhan dunia maupun kebutuhan di akhirat. Pemerintah Negara Republik Indonesia memberikan jaminan yang diatur dalam UUD tahun 1945 yaitu dalam Bab X Tentang Hak Azasi Manusia (HAM), khususnya yang diatur dalam pasal $28 \mathrm{H}$ ayat (1) yang menyebutkan bahwa: " Setiap warga negara berhak hidup sejahtera lahir dan batin, bertempat tinggal, dan mendapatkan lingkungan hidup yang baik dan sehat serta berhak memperoleh pelayanan kesehatan".

\section{Kasus/Masalah}

Pentingnya kegiatan penyuluhan hukum ini diberikan kepada masyarakat khususnya warga prolanis yang ada dalam pelayanan puskesmas grogol "RAHMATIKA", agar masyarakat warga pada puskesmas grogol ini mengetahui dan memahami bahwa sebagai Warga Negara memiliki Hak untuk mendapat pelayanan kesehatan yang dijamin oleh Negara berdasarkan UUD 1945. Negara dalam hal ini Pemerintah Republik 
Indonesia sangat memperhatikan kebutuhan masyarakat dalam menjaga kesehatan setiap warga negaranya. Masih banyak warga negara yang belum memahami tentang pelayanan kesehatan yang telah dijamin negara melalui pelaksanaan UU Kesehatan.

\section{Tinjauan pustaka}

Dalam penyuluhan ini dijelaskan tentang a. Apa yang dimaksud dengan Hak dan Kewajiban sebagai hak warga negara; b. Bagaimana UUD Tahun 1945 mengatur tentang Hak dan kewajiban Warga Negara Republik Indonesia; c. Apa saja yang dimaksud dengan fasilitas kesehatan; d. Bagaimana setiap warga negara Republik Indonesia memiliki Hak untuk mendapatkan pelayanan kesehatan bagi diri maupun keluarganya untuk mendapatkan pelayanan kesehatan yang diatur dalam UUD Tahun 1945. Demikian pula juga dijelaskan tentang UU Nomor 36 Tahun 2009 tentang kesehatan. Ruang lingkup kesehatan, pelayanan, serta hak-hak Pasien. Tumbuhnya kesadaran untuk mengetahui betapa pentingnya mengetahui dan memahami akan hak warga negara yang diatur dalam UUD Tahun 1945, maka setiap warga negara diharapkan menggunakan hak-haknya dengan sebaik-baiknya seimbang dengan kewajiban-kewajibannya.

\section{Pembahasan}

Penyuluhan hukum tetap diperlukan dan terus dilaksanakan terprogram secara berkesinambungan agar setiap warga negara mampu memahami tentang Peraturan Hukum yang 
berlaku di Negara Kesatuan Republik Indonesia, serta menjalankan hukum itu dengan segala konsekuensinya.

Setiap hukum memiliki sanksi hukum, sehingga masyarakat diharapkan sadar akan hukum dan memenuhi sanksi apabila melakukan pelanggaran hukum. Hal ini akan menegaskan bahwa negara Republik Indonesia merupakan negara hukum. Informasi yang baik dan benar akan mengiringi langkah masyarakat dalam melaksanakan tanggung jawab, Hak dan kewajiban sebagai warga negara yang baik.

\section{Kesimpulan}

Pentingnya untuk memahami hak-hak dan kewajiban sebagai Warga Negara Kesatuan Republik Indonesia untuk mendapatkan pelayanan kesehatan yang telah dijamin oleh Pemerintah Negara Kesatuan Republik Indonesia telah diatur dalam UUD Tahun 1945, khususnya pada pembukaan UUD Tahun 1945 khususnya dalam alinea ke-empat serta pada ketentuan Bab XA Pasal 28 huruf $\mathrm{H}$.

\section{Daftar pustaka}

Buku:

Adik Wibowo, 2017, kesehatan masyarakat Di Indonesia, Konsep, Aplikasi dan Tantangan, Penerbit: Rajawali pers, Jakarta.

Yeni Lestari, Dodik Aprilianto, Joko Pramono,2018, Kesehatan Masyarakat, penerbit ANDI, Edisi Revisi.

Peraturan Perundang - undangan: 


\section{UUD Tahun 1945}

UU RI. No: 36 Tahun 2009 tentang Kesehatan

Undang-Undang Nomor 32 Tahun 2004 tentang Pemerintah Daerah sebagaimana telah diubah terakhir dengan UndangUndang Nomor 12 Tahun 2008 tentang perubahan kedua Atas Undang- Undang nomor 32 Tahun 2008 tentang Pemerintah Daerah. 